\title{
Analisis Kadar Kalium Sorbat Dalam Minuman Ringan Yang Dijual Bebas Di Kabupaten Pekalongan Dengan Metode Hplc
}

\author{
Diana Safitri ${ }^{1}$, WWirasti $^{2 *}$, Khusna Santika Rahmasari ${ }^{3}$, S Slamet $^{4}$ \\ ${ }^{1,2,3,4}$ Prodi Sarjana Farmasi, Universitas Muhammadiyah Pekajangan Pekalongan, Indonesia \\ *email:wirsti.kharis@gmail.com
}

\begin{abstract}
Potassium sorbate is one type of preservative that is often added in soft drinks. The addition is to inhibit and prevent the process of fermentation, acidification or other forms of destruction, or is an ingredient that can protect food from spoilage. The purpose of this study was to analyze the content of potassium preservatives in soft drink samples and to determine whether the levels of potassium sorbate in soft drinks were in accordance with the standards set by BPOM RI Number 36 of 2013 concerning the maximum limit for the use of food additives potassium sorbate which is $25 \mathrm{mg} / \mathrm{kg}$ body weight. The methods used in this research are qualitative and quantitative methods. The qualitative analysis used is the Color Test Method. The quantitative analysis used is High Performance Liquid Chromatography (HPLC) with methanol acetonitril as the mobile phase. The results obtained from the color test of the sample change the color of the sample to pink according to the comparison color while the HPLC results obtained that the sample content is calculated in each total volume, namely M1 $=0.051 \mathrm{mg} / \mathrm{kg} \mathrm{BW}, \mathrm{M} 2=0.226 \mathrm{mg} / \mathrm{kg} \mathrm{BW}, \mathrm{M} 3=0.209 \mathrm{mg} / \mathrm{kg} \mathrm{BW}, \mathrm{M} 4=0.103$ $\mathrm{mg} / \mathrm{kg} \mathrm{BW}, \mathrm{M} 5=0.322 \mathrm{mg} / \mathrm{kg} \mathrm{BW}, \mathrm{M} 6=0.150 \mathrm{mg} / \mathrm{kg} \mathrm{BW}, \mathrm{M} 7=0.173 \mathrm{mg} / \mathrm{kg} \mathrm{BW}, \mathrm{M} 8=$ $0.127 \mathrm{mg} / \mathrm{kg} \mathrm{BW}, \mathrm{M} 9=0.195 \mathrm{mg} / \mathrm{kg} \mathrm{BW}, \mathrm{M} 10=0.185 \mathrm{mg} / \mathrm{kg} \mathrm{BW}, \mathrm{M} 11=0.107 \mathrm{mg} / \mathrm{kg}$ BW and $M 12=0.174 \mathrm{mg} / \mathrm{kg} B W$. It can be said that samples $M 1$ to $M 12$ meet the requirements for potassium sorbate levels set by BPOM RI Number 36 of 2013.
\end{abstract}

Keywords: soft drinks, potassium sorbate, preservatives, content analysis, HPLC.

\begin{abstract}
Abstrak
Kalium sorbat adalah salah satu jenis zat pengawet yang sering ditambahkan dalam minuman ringan. Penambahan tersebut untuk menghambat dan mencegah proses fermentasi, pengasaman atau bentuk perusakan lainnya, atau merupakan bahan yang dapat melindungi pangan dari pembusukan. Tujuan dari penelitian ini adalah untuk menganalisis kandungan pengawet kalium sorbatdalam sampel minuman ringan dan untuk mengetahui apakah kadar kalium sorbatdalam minuman ringan sudah sesuai dengan standar yang telah ditetapkan oleh BPOM RI Nomor 36 Tahun 2013 tentang batas maksimal penggunaan bahan tambahan pangan kalium sorbatyaitu sebesar $25 \mathrm{mg} / \mathrm{kg}$ berat badan. Metode yang digunakan pada penelitian ini adalah metode kualitatif dan kuantitatif. Analisis kualitatif yang digunakan yaitu Metode Uji Warna. Analisis kuantitatif yang digunakan yaitu High Performance Liquid Chromatography (HPLC) dengan fase gerak metanol asetonitril. Hasil yang diperoleh dari uji warna terjadi perubahan warna sampel menjadi berwarna merah muda sesuai dengan warna pembanding sedangkan dengan hasil HPLC diperoleh kadar sampel yang dihitung dalam tiap jumlah total volume sampel yaitu $M 1=0,051 \mathrm{mg} / \mathrm{kg} \mathrm{BB}, M 2=0,226 \mathrm{mg} / \mathrm{kg} \mathrm{BB}, \mathrm{M3}=0,209$ $\mathrm{mg} / \mathrm{kg} \mathrm{BB}, \mathrm{M} 4=0,103 \mathrm{mg} / \mathrm{kg} \mathrm{BB}, \mathrm{M} 5=0,322 \mathrm{mg} / \mathrm{kg} \mathrm{BB}, \mathrm{M} 6=0,150 \mathrm{mg} / \mathrm{kg} \mathrm{BB}, \mathrm{M7}=0,173$ $\mathrm{mg} / \mathrm{kg} \mathrm{BB}, \mathrm{M} 8=0,127 \mathrm{mg} / \mathrm{kg} \mathrm{BB}, \mathrm{M} 9=0,195 \mathrm{mg} / \mathrm{kg} \mathrm{BB}, \mathrm{M} 10=0,185 \mathrm{mg} / \mathrm{kg} \mathrm{BB}, \mathrm{M} 11=$ $0,107 \mathrm{mg} / \mathrm{kg}$ BB dan M12 = 0,174 mg/kg BB. Dapat disimpulkan bahwa sampel M1 sampai M12 memenuhi persyaratan kadar kalium sorbatyang ditetapkan oleh BPOM RI Nomor 36 Tahun 2013.
\end{abstract}

Kata Kunci: minuman ringan, kalium sorbat, pengawet, analisis kadar, HPLC. 


\section{Prosiding Seminar Nasional Kesehatan $\mathbf{2 0 2 1}$ Lembaga Penelitian dan Pengabdian Masyarakat Universitas Muhammadiyah Pekajangan Pekalongan}

\section{Pendahuluan}

Tumbuhnya industri makanan dan minuman di Indonesia, menyebabkan produksi minuman ringan yang beredar di masyarakat semakin meningkat. Konsumsi minuman ringan dari negara-negara di dunia semakin meningkat. Minuman ini bahkan di konsumsi $74 \%$ dari populasi anak-anak dan remaja. Pembuatan minuman ringan atau soft drink sering ditambahkan pengawet buatan. Keuntungan menggunakan bahan pengawet adalah membebaskan makanan dari kehidupan mikro organisme. Sehingga banyak produsen minuman ringan menggunakan pengawet, dalam hal ini adalah kalium sorbat. Konsumsi bahan pengawet yang berlebihan akan membahayakan kesehatan. Oleh karena itu, kadar atau takaranya harus diperhatikan (Tania, 2016).

Kalium sorbat atau potassium sorbat adalah salah satu jenis pengawet popular dalam produk minuman. Kalium sorbat diolah secara sintetis dari asam sorbat dan kalium hidroksida. Pengawet ini memiliki karakteristik tidak berbau serta tidak berasa sehingga cocok digunakan dalam produk minuman. Sebagai pengawet dalam produk olahan, kalium sorbat membantu memperpanjang umur simpan produk dengan menghentikan pertumbuhan jamur.

Kromatografi Cair Kinerja Tinggi/High Performance Liquid Chromatography (HPLC) merupakan metode terpilih untuk analisis campuran bahan tambahan, Karena zat-zat tersebut bersifat polar dan larut dalam air sehingga sulit untuk dipisahkan. Analisis dengan HPLC memiliki kelebihan seperti analisa lebih cepat, daya pisah baik, kepekaan tinggi, penyiapan sampel relative mudah dan dapat dihubungkan dengan detektor yang sesuai. (Hayun, 2014). Metode ini Dapat digunakan untuk menganalisis kadar kalium sorbat dalam minuman ringan.

Tujuan dilakukanya penelitian ini yaitu untuk mengetahui kadar kalium sorbat dalam minuman ringan yang dijual bebas di Kabupaten Pekalongan dan mengetahui kesesuaian kadar kalium sorbat yang terkandung di dalam minuman ringan yang beredar di Kabupaten Pekalongan dengan standar yang telah ditetapkan oleh BPOM RI Nomor 36 Tahun 2013 tentang batas penggunaan bahan tambahan pangan.

\section{Metode}

Alat dan bahan

Alat-alat yang digunakan dalam penelitian ini diantaranya seperangkat instrument High Performance Liquid Chormatography (HPLC) dengan detektor UV (Shimadzu SPD20A), kolom C18 dimensi $250 \times 4,6 \mathrm{~mm}$ dan ukuranpori $5 \mu \mathrm{m}$ (YMC Triart C18), ultrasonic (biobase), spektrofotometer UV-Vis (Shimdzu UV-Vis 1280), timbangan analitik (Ohauss), kertas saring whattman no. 41 , mikrofilter $0,45 \mu \mathrm{m}$, kuvet (Shimadzu), pipet mikro (Merck), penangas air alat-alat gelas (pyrex).

Bahan-bahan yang digunakan dalam penelitian ini diantaranya dua belas sampel minuman ringan yang dijual bebas di Kabupaten Pekalongan, baku kalium sorbat p.a, aqua bidest, asam kromat p.a, asam tiobarbiturat p.a.

Jalannya penelitian

1. Analisis kualitatif (Uji warna)

Digunakan $1 \mathrm{ml}$ sampel ditambahkan aquadestilata dan larutan asam kromat kemudian di didihkan, setelah mendidih ditambahkan larutan $0.3 \%$ asam 


\section{Prosiding Seminar Nasional Kesehatan Lembaga Penelitian dan Pengabdian Masyarakat Universitas Muhammadiyah Pekajangan Pekalongan}

tiobarbiturat sedikit demi sedikit. Hasil positif ditandai dengan warna merah muda atau kemerahan.

2. Analisis kuantiatif (HPLC)

a. Pengumpulan sampel minumanringan didapat dari pasar tradisional, pedagang kaki lima dan mini market lokal di Kabupaten Pekalongan. Preparasi sampel dilakukan dengan cara pengenceran kedua belas merk sampel dengan aquabidest dan digojok serta disaring dengan microfilter $0,45 \mu \mathrm{m}$ dan disonikasi 15 menit. Untuk fase gerak aquabidest juga dilakukan penyaringan dan sonikasi.

b. Pembuatan larutan baku kalium sorbet dibuat dengan konsentrasi 1.000 $\mu \mathrm{g} / \mathrm{mL}$ sementara larutan seri dalam konsentrasi $0,5,1,2,3$ dan $4 \mu \mathrm{g} / \mathrm{mL}$. Dilakukan penyaringan dan sonikasi. Penentuan panjang gelombang dilakukan dengan cara scanning panjang gelombang baku kalium sorbat pada $\lambda$ spektrofotometer UV dan hasil digunakan untuk analisis HPLC.

c. Pengamatan waktu retensi kalium sorbet dilakukan dengan cara larutan baku diinjeksikan pada HPLC dengan kecepatan alir fasegerak $1 \mathrm{~mL} / \mathrm{menit}$. Hasil dilihat pada kromatogram.

d. Pembuatan kurva baku dilakukan dengan menginjekan seri konsentrasi pada HPLC dan digunakan nilai AUC untuk mendapatkan persamaan regresi linier.

e. Penetapan kadar dilakukan dengan menginjekan larutan hasil penyiapan sampel volume $20 \mu \mathrm{l}$ pada HPLC. Ditentukan konsentrasi kalium sorbet dengan cara nilai AUC dari kedua belas sampel disubtitusikan dalam persamaan regresi linier. Kemudian dihitung kadarnya dalam satuan $\mathrm{mg} / \mathrm{kg}$ BB dengan rumus:

$$
\text { Kadar }=\frac{\operatorname{kadar}\left(\frac{\mathrm{b}}{\mathrm{v}}\right) \text { tiap volume kemasan }}{\text { rata-rata BB orang dewasa }(\mathrm{kg})}
$$

\section{Hasil dan Pembahasan}

Semua merk sampel merupakan produksi industry pabrik dan industry rumah tangga Indonesia yang memiliki ijin BPOM atau P-IRT. Termasuk jenis minuman ringan non soda, yaitu sejenis kopi, teh, susu, kopi susu, sari buah, minuman ringan dengan jelly dan minuman isotonik. Dalam komposisi pada kemasan tercantum bahan pengawet, yaitu kalium sorbat.

Pengawet kalium sorbat merupakan bentuk garam yang lebih efektif dibandingkan dengan bentuk asam sorbat. Akan tetapi, apa bila dikonsumsi melebihi batas maksimal, dapat menimbulkan efek samping kesehatan yang merugikan sehinggga diperlukan analisis untuk menetapkan kadar.

Analisis kalium sorbat dalam penelitian ini menggunakan 2 metode yaitu analisis kualitatif dan analisis kuantitatif. Analisis kualitatif dalam penelitian ini dilakukan dengan uji perubahan warna. Keberadaan kalium sorbat menunjukan warna merah atau merah muda setelah penambahan larutan asam kromat dan tiobarbiturat (Ribeiro, dkk., 2018). Penambahan kedua bahan sebagai pengoksidasi dan menyebabkan zat lain mengalami proses oksidasi yaitu reaksi yang melepaskan atau menghasilkan 


\section{Prosiding Seminar Nasional Kesehatan Lembaga Penelitian dan Pengabdian Masyarakat Universitas Muhammadiyah Pekajangan Pekalongan

oksigen (Nurlela, 2017). Terbentuknya kompleks warna kemerahan pada uji ini disebabkan oleh terjadinya proses oksidasi kalium sorbat menjadi malonat aldehid. Kemudian reaksi selanjutnya sebagaimana Gambar 1.

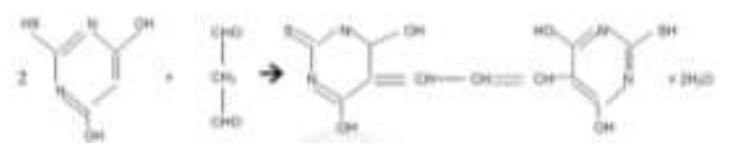

Asam Malonat Kompleks warna merah tiobar biturat aldehid

Gambar 3.1 Reaksi kimia malonat aldehid dengan asam tiobarbiturat (Prasetyo,2017).

Kedua belas sampel menunjukan perubahan warna (Tabel 1). Hasil ini sesuai dengan peneitian oleh Ribeiro (2018). Dapat diartikan bahwa kedua belas merk sampel minuman ringan positif mengandung kalium sorbat.

Tabel 3.1 Hasil uji kualitatif kalium sorbat

\begin{tabular}{ccc}
\hline Nama sampel & & Hasil \\
\hline $\begin{array}{c}\text { Baku } \\
\text { kaliumsorbat }\end{array}$ & + (orange kemerahan) \\
M1 & ++ (orange kemerahan) \\
M2 & + & (orange kemerahan) \\
M3 & + & (orange kemerahan) \\
M4 & + & (orange kemerahan) \\
M5 & + & (orange kemerahan) \\
M6 & + & (orange kemerahan) \\
M7 & + & (orange kemerahan) \\
M8 & + & (orange kemerahan) \\
M9 & ++ (orange kemerahan) \\
M10 & + & (orange kemerahan) \\
M11 & ++ (orange kemerahan) \\
M12 & + & (orange kemerahan) \\
\hline
\end{tabular}

Larutan induk adalah larutan baku dengan konsentrasi tinggi dan digunakan dalam pembuatan larutan seri kalium sorbat dalam konsentrasi yang lebih rendah. Sementara larutan seri dibuat untuk menghasilkan kurva baku kalium sorbat dan penetapan $\lambda_{\max }$ yang diukur dalam rentang UV dikarenakan, larutan kalium sorbat dalam aquadest tidak memiliki warna tampak (Gandjar, 2012). $\lambda_{\max }$ kalium sorbat dalam penetapan ini yaitu $255,5 \mathrm{~nm}$. Hasil ini mirip dengan penelitian yang dilakukan oleh Harry (2000) yaitu $\lambda_{\max }$ sebesar $255 \mathrm{~nm}$. Keterbacaan absorbansi dikarenakan senyawa kalium sorbat memiliki gugus kromofor yang dapat menyerap radiasi UV dan gugus auksokrom yang dapat meningkatkan penyerapan radiasinya kromofor dan gugus auksokrom (Chrismaaji, 2018)

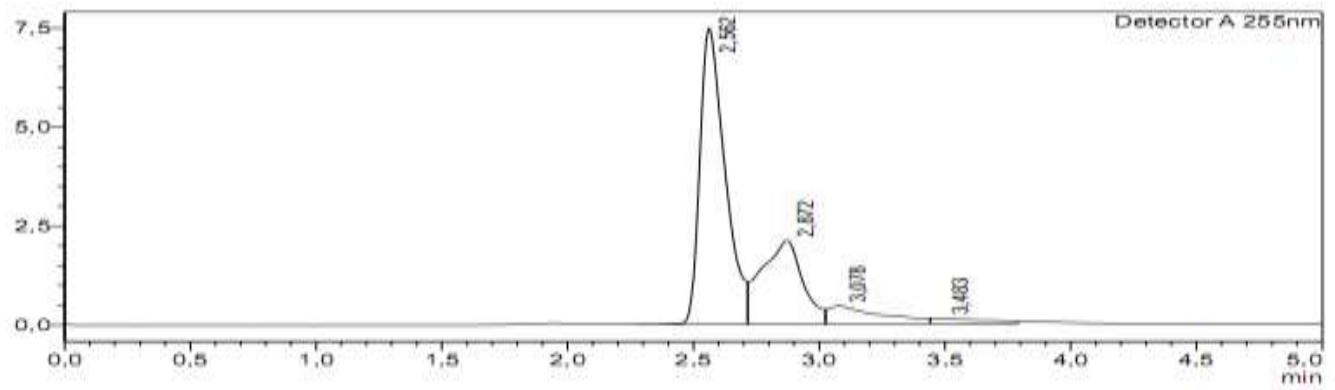




\section{Prosiding Seminar Nasional Kesehatan 2021 Lembaga Penelitian dan Pengabdian Masyarakat Universitas Muhammadiyah Pekajangan Pekalongan}

Gambar 3.2 Hasil peak kromatogram kalium sorbat konsentrasi $0,5 \mu \mathrm{g} / \mathrm{mL}$

Analisis kuantitatif dengan metode HPLC menunjukan hasil kromatogram berupa peak.Hasil peak baku dan sampel M1-M12 sama-sama baik, keduanya memiliki bentuk peak yang runcing. Adapun contoh peak dari baku kalium sorbat dan analit sampel minuman ringan pada Gambar 3.3 dan Gambar 3.3

Gambar 3.2 Menunjukan jumlah lebih dari 1 peak sebagai mana seri lain. Hal ini menunjukan masih adanya senyawa pengotor yang dapat berasal dari larutan yang diinjekan ataupun dari kolom yang jenuh. Bentuk peak ini runcing dan terlihat pada menit ke-2,4 dan puncaknya terdeteksi pada menit ke-2,562.

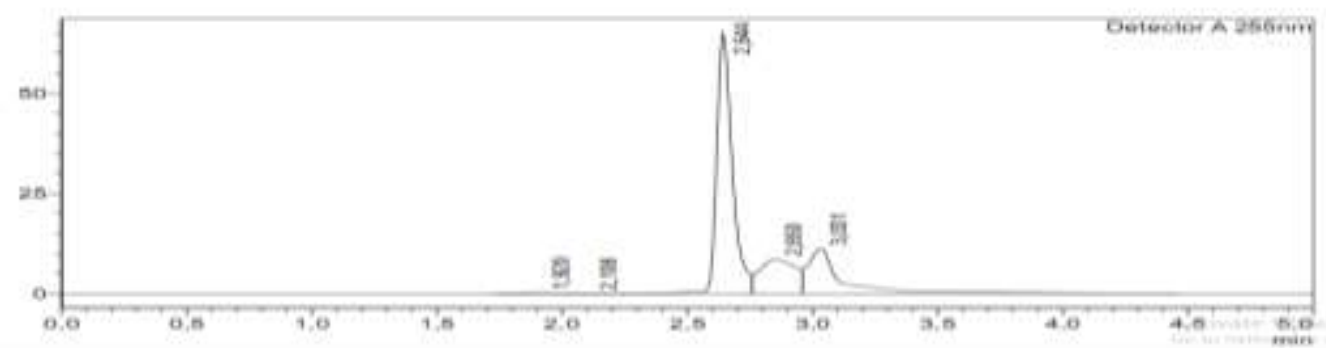

Gambar 3.3 Hasil peak kromatogram dari sampel 10 replikasi 1

Gambar 3.3 Menunjukan contoh peak yang dihasilkan dari sampel minuman ringan dengan bentuk peak yang runcing. Jumlah peak yang dihasilkan dari masingmasing merk sampel lebihdari 1 peak. Hal ini dikarenakan adanya senyawa pengotor lain. Pengotor ini tidak menjadi masalah karena, dalam sampel minuman ringan memang terdiri dari beberapa senyawa. Dalam penelitian seperti ini tidak dilakukan pemurnian senyawa, dikarenakan masing-masing merk sampel memiliki susunan komposisi bahan yang berbeda.

Waktu retensi yaitu waktu yang dibutuhkan senyawa analit dari fase diam sampai kedetektornya (Supriyanto, 2018). Adapun waktu retensi baku kalium sorbat yang dihasilkan dalam penelitian ini yaitu sekitar 2,5 menit dengan standar deviasi yang baik yaitu 0,012 .

Waktu retensi yang dihasilkan dari berbagai merk sampel minuman ringan dalam penelitian ini tertera pada Tabel 3.2 Yaitu berkisar pada 2,5 dan 2,6 menit. Waktu retensi ini mirip dengan waktu retensi baku kalium sorbat.

Tabel 3.2 Nilai waktu retensi $\left(t_{R}\right)$ sampel

\begin{tabular}{cccccc}
\hline Nama & \multicolumn{5}{c}{ Waktu retensi (menit) } \\
\cline { 2 - 6 } Sampel & Replikasi 1 & $\begin{array}{c}\text { Replikasi } \\
2\end{array}$ & Replikasi 3 & $\begin{array}{c}\text { Rata- } \\
\text { rata }\end{array}$ & I SD \\
\hline M1 & 2,561 & 2,573 & 2,561 & 2,565 & \\
M2 & 2,584 & 2,584 & 2,584 & 2,584 & \\
M3 & 2,579 & 2,579 & 2,579 & 2,579 & \\
M4 & 2,645 & 2,645 & 2,645 & 2,645 & \\
M5 & 2,662 & 2,662 & 2,662 & 2,662 & \\
M6 & 2,648 & 2,646 & 2,646 & 2,647 & $\pm 0,033$ \\
M7 & 2,646 & 2,646 & 2,646 & 2,646 & \\
M8 & 2,652 & 2,639 & 2,652 & 2,648 & \\
M9 & 2,654 & 2,654 & 2,654 & 2,654 & \\
M10 & 2,644 & 2,648 & 2,644 & 2,645 & \\
M11 & 2,641 & 2,650 & 2,650 & 2,647 & \\
M12 & 2,636 & 2,636 & 2,636 & 2,636 & \\
\hline
\end{tabular}




\section{Prosiding Seminar Nasional Kesehatan \\ Lembaga Penelitian dan Pengabdian Masyarakat Universitas Muhammadiyah Pekajangan Pekalongan}

Nilai AUC dari larutan seri tertera pada Tabel 3.3 Hasil ini sesuai karena, menunjukan semakin meningkatnya konsentrasi maka meningkat pula AUC.

Tabel 3.3 AUCdan regresi linier

\begin{tabular}{ccc}
\hline $\begin{array}{c}\text { Konsentrasi } \\
(\mu \mathrm{g} / \mathrm{mL})\end{array}$ & AUC & Persamaan regresi linier \\
\hline & & \\
\hline 0,5 & 52548 & \\
1 & 132502 & $\mathrm{Y}=\mathrm{b} x+\mathrm{a}$ \\
2 & 282175 & $\mathrm{Y}=146477 x-16447,9$ \\
3 & 419074 & \\
4 & 569469 & \\
\hline $\mathrm{B}$ & 146477 & \\
$\mathrm{~A}$ & 16447,9 & \\
$\mathrm{r}^{2}$ & 0,9995935 & \\
\hline
\end{tabular}

Persamaan regresi linier yang didapatkan dari kurva baku kalium sorbat digunakan untuk mensubtitusikan nilai AUC sampel M1-M12 pada Tabel 3.4 sampel M1 memiliki rerata nilai AUC paling kecil, sedangkan sampel M5 memiliki rerata nilai AUC paling besar. Hal ini akan menentukan nilai konsentrasinya dengan semakin besarnya nilai AUC maka menghasilkan konsentrasi analit yang lebih besar.

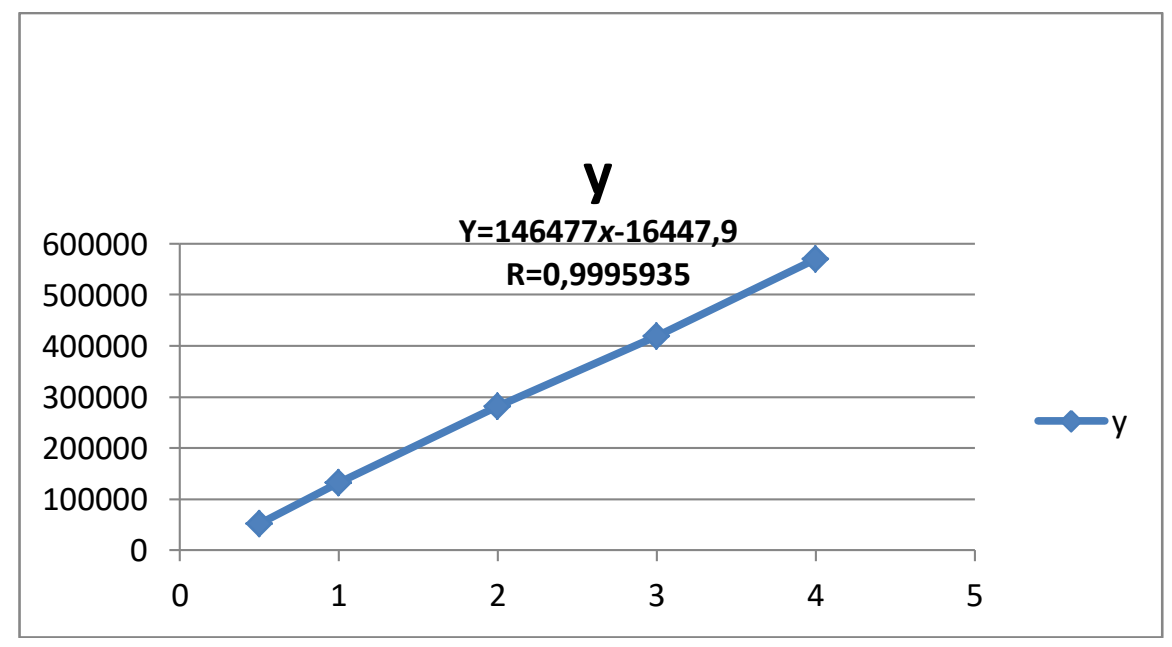

Gambar 3.4 Kurva standard kalium sorbat

Hasil dari nilai AUC seri konsentrasi kalium sorbat menentukan linieritas seperti pada kurva baku kalium sorbat Gambar 4 . Hasillinieritas $\left(r^{2}\right)$ baik, karena memiliki nilai $>0,99$ yang menunjukan hubungan yang linier antara peningkatan konsentrasi seri kalium sorbat dengan respon instrumen HPLC yang digunakan (AOAC, 2013).

Tabel 3.4 Luas area (AUC) sampel

\begin{tabular}{ccccc}
\hline Nama & \multicolumn{3}{c}{ AUC } \\
\cline { 2 - 5 } Sampel & Replikasi. 1 & Replikasi. & Replikasi 3 & Rata-rata \\
\hline M1 & 83965 & 75555 & 83781 & 81100,3333 \\
M2 & 172863 & 172815 & 172743 & 172807 \\
M3 & 158409 & 158340 & 158285 & 158344,667 \\
M4 & 136162 & 135786 & 133623 & 135190,333 \\
M5 & 508813 & 508287 & 507492 & 508197,333 \\
M6 & 470309 & 470779 & 471086 & 470724,667 \\
M7 & 321232 & 321028 & 323101 & 321787 \\
M8 & 219194 & 210731 & 219627 & 216517,333 \\
M9 & 362727 & 363629 & 368337 & 364897,667 \\
M10 & 284668 & 284487 & 284487 & 284547,333 \\
M11 & 214801 & 217324 & 217050 & 216391,667 \\
M12 & 301088 & 303660 & 301416 & 302054,667 \\
\hline
\end{tabular}




\section{Prosiding Seminar Nasional Kesehatan $\mathbf{2 0 2 1}$ Lembaga Penelitian dan Pengabdian Masyarakat Universitas Muhammadiyah Pekajangan Pekalongan}

Hasil perhitungan konsentrasi kalium sorbat pada sampel minuman ringan sebagaimana Tabel 3.5 perhitungan berdasarkan nilai AUC yang disubtitusikan pada persamaan regresi linier $Y=146477 x-16447,9$.

Tabel 3.5 Konsentrasi kalium sorbat pada sampel

\begin{tabular}{cccccc}
\hline Namaa & \multicolumn{5}{c}{ Konsentrasi $(\mu \mathrm{g} / \mathrm{mL})$} \\
\cline { 2 - 6 } Sampel & Replikasj. 1 & Replikasi. 2 & Replikasi 3 & $\begin{array}{c}\text { Rata- } \\
\text { rata }\end{array}$ & $\pm \mathrm{SD}$ \\
\hline M1 & 0,686 & 0,628 & 0,684 & 0,666 & 0,027 \\
M2 & 1,292 & 1,292 & 1,292 & 1,292 & 0,000 \\
M3 & 1,194 & 1,193 & 1,193 & 1,193 & 0,001 \\
M4 & 1,042 & 1,039 & 1,025 & 1,035 & 0,007 \\
M5 & 3,586 & 3,582 & 3,577 & 3,582 & 0,005 \\
M6 & 3,323 & 3,326 & 3,328 & 3,326 & 0,002 \\
M7 & 2,305 & 2,304 & 2,318 & 2,309 & 0,006 \\
M8 & 1,609 & 1,551 & 1,612 & 1,590 & 0,028 \\
M9 & 2,589 & 2,595 & 2,627 & 2,604 & 0,017 \\
M10 & 2,056 & 2,054 & 2,054 & 2,055 & 0,001 \\
M11 & 1,579 & 1,596 & 1,594 & 1,590 & 0,008 \\
M12 & 2,168 & 2,185 & 2,170 & 2,174 & 0,007 \\
\hline
\end{tabular}

Sampel M1 memiliki konsentrasi kalium sorbat terendah, sedangkan sampel M5 memiliki konsentrasi kalium sorbat tertinggi.

Kadar yaitu jumlah banyaknya kandungan senyawa kalium sorbat dalam tiap satuan volume sampel minuman ringan. Kadar awal dinyatakan dalam satuan $\mu \mathrm{g} / \mathrm{mL}$. Kedua belas sampel memiliki rerata kadar sebagai mana Tabel 3.6 Semua data kadar ini memiliki variasi data yang baik karena nilai SD kecil.

Tabel 3.6 Kadar (b/v) kalium sorbat pada sampel minuman ringan

\begin{tabular}{cccccc}
\hline Nama & \multicolumn{5}{c}{ Kadar $(\mu \mathrm{g} / \mathrm{mL})$} \\
\cline { 2 - 6 } Sampel & Replikasi. 1 & Replikasi. 2 & Replikasi. 3 & Rata-rata & \pm SD \\
\hline M1 & 17,150 & 17,050 & 17,100 & 17,100 & 0,041 \\
M2 & 32,300 & 32,300 & 32,300 & 32,300 & 0,000 \\
M3 & 29,850 & 29,825 & 29,825 & 29,833 & 0,012 \\
M4 & 26,050 & 25,975 & 25,625 & 25,883 & 0,185 \\
M5 & 89,650 & 89,550 & 89,425 & 89,542 & 0,092 \\
M6 & 83,075 & 83,150 & 83,200 & 83,142 & 0,051 \\
M7 & 57,625 & 57,600 & 57,950 & 57,725 & 0,159 \\
M8 & 40,225 & 38,775 & 40,300 & 39,767 & 0,702 \\
M9 & 64,725 & 64,875 & 65,675 & 65,092 & 0,417 \\
M10 & 51,400 & 51,350 & 51,350 & 51,367 & 0,024 \\
M11 & 39,475 & 39,900 & 39,850 & 39,742 & 0,190 \\
M12 & 54,200 & 54,625 & 54,250 & 54,358 & 0,190 \\
\hline
\end{tabular}

Sampel M1 memiliki kadar kalium sorbat terendah, sedangkan sampel M5 memiliki kadar kalium sobat tertinggi yaitu sebesar.

Tabel 3.7 Rata-rata kadar kalium sorbat tiap vol kemasan sampel

\begin{tabular}{ccc}
\hline $\begin{array}{c}\text { Nama } \\
\text { sampel }\end{array}$ & $\begin{array}{c}\text { Volume tiap } \\
\text { kemasan }(\mathrm{ml})\end{array}$ & $\begin{array}{c}\text { Rata-rata kadar tiap volume } \\
\text { kemasan }(\mathrm{mg})\end{array}$ \\
\hline M1 & 150 & 2,565 \\
M2 & 350 & 11,305 \\
M3 & 350 & 10,445 \\
M4 & 200 & 5,177 \\
M5 & 180 & 16,118 \\
M6 & 90 & 7,483 \\
M7 & 150 & 8,659 \\
M8 & 160 & 6,363 \\
M9 & 150 & 9,763 \\
M10 & 180 & 9,246 \\
M11 & 135 & 5,365 \\
M12 & 160 & 8,697 \\
\hline
\end{tabular}




\section{Prosiding Seminar Nasional Kesehatan Lembaga Penelitian dan Pengabdian Masyarakat Universitas Muhammadiyah Pekajangan Pekalongan

Dalam satuan kadar $\mathrm{mg} / \mathrm{mL}$ total volume kemasan, masing-masing sampel M1M12 memiliki rata-rata kadar sebagai mana pada Tabel 3.7 Masing-masing sampel memiliki kadar kalium sorbat dari yang terendah hingga tertinggi, yaitu M1, M4, M11, M8, M6, M7, M12, M10, M9, M3, M2 = dan M5.

Tabel 3.8 Kadar rata-rata kalium sorbat $(\mathrm{mg} / \mathrm{kg} \mathrm{BB})$ pada sampel minuman

\begin{tabular}{cc}
\hline $\begin{array}{c}\text { Nama } \\
\text { sampel }\end{array}$ & $\begin{array}{c}\text { Kadar rata-rata kalium sorbat } \\
(\mathrm{mg} / \mathrm{kg} \mathrm{BB})\end{array}$ \\
\hline M1 & 0,051 \\
M2 & 0,226 \\
M3 & 0,209 \\
M4 & 0,103 \\
M5 & 0,322 \\
M6 & 0,150 \\
M7 & 0,173 \\
M8 & 0,127 \\
M9 & 0,195 \\
M10 & 0,185 \\
M11 & 0,107 \\
M12 & 0,174 \\
\hline
\end{tabular}

Kadar rata-rata kalium sorbat masing-masing merk sampel dalam satuan $\mathrm{mg} / \mathrm{kg}$ BB adalah sebagai mana Tabel 3.8 Kadar kalium sorbat terendah yaitu pada sampel minuman ringan merk M1 sebesar 0,051 mg/kg BB. Sedangkan kadar kalium sorbat tertinggi yaitu pada sampel minuman ringan merk M5 sebesar 0,322 mg/kgBB.

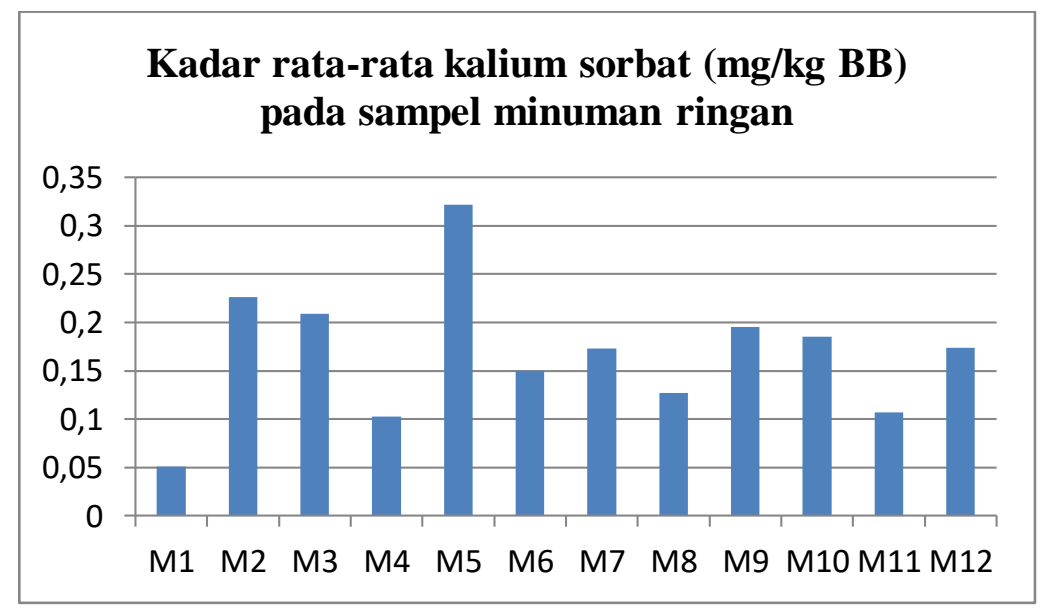

Gambar 3.5 Kadar rata-rata kalium sorbat

Kadar rata-rata kalium sorbat masing-masing merk sampel dalam satuan $\mathrm{mg} / \mathrm{kg}$ BB juga digambarkan dalam diagram Gambar 3.5 Kadar kalium sorbat tertinggi dalam penelitian ini tidak melebihi batas maksimal yang ditetapkan oleh peraturan BPOM. Hal ini dapat diartikan bahwa semua merk sampel minuman ringan memiliki rata-rata kadar kalium sorbat yang memenuhi persyaratan oleh BPOM RI Nomor 36 Tahun 2013 mengenai penggunaan kalium sorbat dalam minuman yang diizinkan yaitu dengan kadar maksimum $25 \mathrm{mg} / \mathrm{kg}$ BB. 


\section{Prosiding Seminar Nasional Kesehatan 2021 Lembaga Penelitian dan Pengabdian Masyarakat Universitas Muhammadiyah Pekajangan Pekalongan}

\section{Kesimpulan}

Berdasarkan penelitian Analisis Kadar Kalium Sorbat dalam Minuman Ringan yang Dijual Bebas di Kabupaten Pekalongan dengan Metode High Performance Liquid Chromatography (HPLC) fase terbalik dengan fase diam oktadesil silika C18, fase gerak metanol asetonitril, laju alir $1 \mathrm{~mL} /$ menit dan panjang gelombang $255 \mathrm{~nm}$. Dapat diambil kesimpulan sebagai berikut:

1. Rata-rata kadar kalium sorbat pada masing-masing merk sampel minuman ringan sampel M1-M12 dalam satuan $\mathrm{mg} / \mathrm{kg}$ BB yaitu $\mathrm{M} 1=0,051 \mathrm{mg} / \mathrm{kg} \mathrm{BB}, \mathrm{M} 2$ $=0,226 \mathrm{mg} / \mathrm{kg} \mathrm{BB}, \mathrm{M3}=0,209 \mathrm{mg} / \mathrm{kg} \mathrm{BB}, \mathrm{M} 4=0,103 \mathrm{mg} / \mathrm{kg} \mathrm{BB}, \mathrm{M} 5=0,322$ $\mathrm{mg} / \mathrm{kg} \mathrm{BB}, M 6=0,150 \mathrm{mg} / \mathrm{kg} \mathrm{BB}, M 7=0,173 \mathrm{mg} / \mathrm{kg} \mathrm{BB}, M 8=0,127 \mathrm{mg} / \mathrm{kg} \mathrm{BB}$, $\mathrm{M} 9=0,195 \mathrm{mg} / \mathrm{kg} \mathrm{BB}, \mathrm{M} 10=0,185 \mathrm{mg} / \mathrm{kg} \mathrm{BB}, \mathrm{M} 11=0,107 \mathrm{mg} / \mathrm{kg}$ BB dan M12 $=0,174 \mathrm{mg} / \mathrm{kg} \mathrm{BB}$.

2. Kedua belas merk sampel minuman ringan yang dijual bebas di Kabupaten Pekalongan ini memiliki kadar ( $\mathrm{mg} / \mathrm{kg} \mathrm{BB}$ ) yang memenuhi persyaratan kadar kalium sorbet yang ditetapkan oleh BPOM RI Nomor 36 Tahun 2013.

\section{Referensi.}

[1] Anonim. 1996.Peraturan UU No. 7/1996 Bab 2, Tentang Bahan Makanan. Jakarta: Departemen kesehatan.

[2] AOAC. 2013. Guideline for Dietary Suplements and Botanical. Maryland, USA: Pharmaceutical Press.

[3] Badan Pengawas Dan Makanan Republik Indonesia. 2013. Peraturan Kepala Badan Pengawas Obat dan Makanan. Badan Pengawas Obat dan Makanan Republik Indonesia.,

[4] Chrismaaji, D.Y. 2018. Penetapan Kadar Kafein dalam Kopi Bubuk Murni Robusta Merk "X" denga Metode High Performance Liquid Chromatography (HPLC) Fase Terbalik. Yogyakarta: Fakultas Farmasi Universitas Sanata Dharma. Skripsi.

[5] Gandjar,I. G., dan Rohman, A. 2012, Analisis obat secara spektrofotometri dan kromatografi. Yogyakarta: Pustaka Pelajar.

[6] Nurlela., Mawardi., \& Kurniati, T. 2017. Kajian Miskonsepsi Siswa Melalui Tes Multiple Choice Menggunakan Certainty of Index Pada Materi Reaksi Reduksi Oksidasi Kelas X MIPA SMAN Pontianak. Ar-Razi Jurnal IImiah. Vol 5, No. 2: 225238.

[7] Prasetyo. 2017. Pengaruh Vitamin C Terhadap Kadar MDA Pada Mahasiswa Kedokteran Universitas Jember Yang Mengalami Stres Psikologi. Jember: Universitas Jember. Skripsi.

[8] Ribeiro, R. D. X, Araujo,G. C. D, Monteiro, N. B, Conte-Junior. C. A, Costa. M. P. D., 2018. Detection of Sorbate Potassium in Brazillian Commercial Fermented Milk : A Review, International Journal of Pharmaceutical Scinces Review and Research.73(4):220-225. 


\section{Prosiding Seminar Nasional Kesehatan 2021 Lembaga Penelitian dan Pengabdian Masyarakat Universitas Muhammadiyah Pekajangan Pekalongan}

[9] Sumartini., Imas, E., dan Bertha, R. 2015. Studi Paparaan Pemanis Buatan pada Minuman Ringan yang Dikomsumsi Siswa/I SMP Negeri 1 Cimaaung Kabupaten Bandung dengan Menggunkan Metode Food Frequency Questionnare, Skripsi, Universitas Islam Bandung.

[10] Tania, M. 2016. Hubungan Pengetahuan Remaja dengan Perilaku Konsumsi Minuman Ringan di SMKN 2 Balendah Bandung, Jurnal Ilmu Keperawatan, Universitas BSI. 4(1):19-25

[11] Wisnu, C., (2016), Analisis dan aspek kesehatan bahan tambahan pangan. Jakarta: Penerbit Bumi Aksara. 